S. I. CONCILIAR TRINITARIANISM

DOI: https://doi.org/10.14428/thl.v4i2.52753

\title{
Can We Predicate of and Speak about God, and What Are the Rules for Doing So? On the Epistemological and Logical Premises of Conciliar Trinitarianism
}

\author{
ANNA ZHYRKOVA \\ Jesuit University Ignatium in Krakow \\ anna.zhyrkova@ignatianum.edu.pl
}

\begin{abstract}
The present study aims to outline the epistemological and logical principles and ground-rules developed during Trinitarian debates by Basil of Caesarea and Gregory of Nyssa: ones which, for the most part, function to define what counts as applicable to and possible for theological discourse when speaking about God. These principles not only underlie Cappadocian Trinitarian theology, but also can be seen as furnishing a key to the proper understanding and interpretation of the Conciliar Trinitarian account, which to a considerable extent was formulated on the basis of and in terms indebted to Cappadocian teaching. As will be argued here, the principles show very clearly the problems associated with addressing God in terms of "essence" - issues that in fact underlie most of the difficulties and incoherences presented by Trinitarian discourse as such.
\end{abstract}

Keywords: Trinity, Knowledge of God, Patristics, Cappadocians, Eunomian controversy

Anyone who intends to advance a form of theological teaching that draws its inspiration from Timothy Pawl's project of "Conciliar Christology" by emulating his endeavors in the domain of Trinitology and attempting to create a "Conciliar Trinitarianism" - in which would be delineated the conjoined claims about the Trinity of the first seven ecumenical councils - will inevitably be confronted by a certain problem: namely, the fact that the Councils produced a quite limited number of doctrinal claims directly relating to Trinitarian questions. Of these, the principal and most pivotal ones are quite easily listed. As is well known, the belief in the consubstantiality of the Son of God with God the Father was ecclesiastically acknowledged as a theological truth by both the Council of Nicaea (325) and the First Council of Constantinople (381), becoming, in consequence, the very touchstone of Christian Trinitarianism. In 
turn, the formula of "one Divine nature/substance in three hypostases" appears in the decrees of the Council of Ephesus (431) and the Second Council of Constantinople (553), both of which are recognized as pertaining to matters of Christology. ${ }^{1}$ Even so, to treat the still extant materials from the debates that took place at the Councils-along with what actually issued from those events in the form of conciliar decrees, canons and anathemas - as a sole and sufficient basis for a complete body of theological teaching would surely be inappropriate. After all, doctrinal claims and formulations, be they positive or negative (as with anathemas), should not be treated as an exposition of orthodox teaching, but rather as normative principles of faith. To be sure, the terse formulations of the conciliar documents and decrees did essentially aim to set out the criteria that would inform the subsequent development of correct and orthodox doctrines; yet they were not self-sufficient, and were never intended to count as an exposition of comprehensive teachings relating to any particular theological question. Rather, they were signs on the road being travelled by theologians engaged in seeking the best possible way to explicate the theological truths received in and through Revelation.

If one hopes to unlock a proper understanding of those signs, then one surely requires their key, which in such cases is to be found in the lines of theological argumentation and substantiation that led up to the particular formulations and expressions of doctrinal principles promulgated by the Ecumenical Councils. In the case of the Conciliar Trinitarian account, we have such a key in the form of the ground rules concerning the very possibility of, and what can be stipulated with respect to, speaking about such a subject as God-i.e. about one who, at least according to the Christian faith, lies beyond any of the intellectual capacities of created beings. Such ground rules were laid down by Basil of Caesarea and Gregory of Nyssa, two Cappadocian defenders of orthodoxy, who in fact had proved most influential at the First Council of Constantinople.

The present study aims to cast light on such matters by outlining the epistemological and logical principles developed during Trinitarian debates by the Cappadocian Fathers-ones which, for the most part, function to define what counts as applicable to theological discourse when speaking about God, as well as in what precise sense, and why and how, this is so. These principles show very clearly the problems associated with addressing God in terms of "substance" and "essence" -issues that in fact underlie most of the difficulties

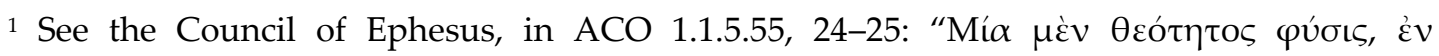

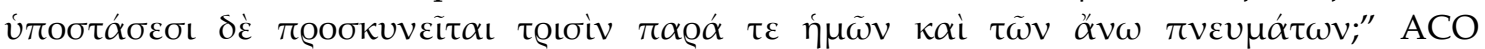

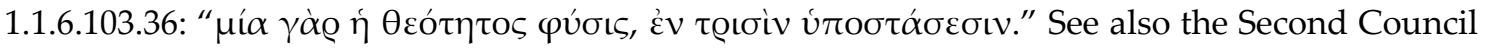

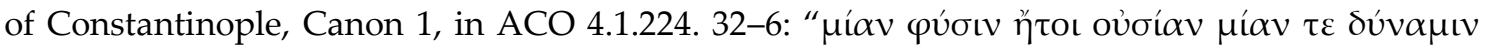

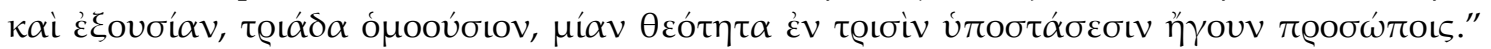
See also Price (2009, 2:120).
} 
and incoherences presented by Trinitarian discourse as such. Given that this is so, it seems reasonable to think that the importance of understanding the epistemological and logical principles laid out by Basil and Gregory extends beyond that which is specifically of concern to practitioners of the history of theology. ${ }^{2}$

\section{Epistemological Presuppositions Concerning Knowledge of God}

The primary epistemological presupposition of any kind of talk about God is obvious, but should still be spelled out, as it seems to quite often be overlooked in the context of many particular lines of Trinitarian argumentation: it is that the human intellect has no knowledge of God except for His existence, and even this knowledge is conditional, to say the least. Basil the Great very generously embraced the view-known for its Epicurean and Stoic roots-according to which the human intellect is endowed with a shared conception of God's existence, one which affirms merely that God exists (Adversus Eunomium [Adv.Eun.], 1.12). ${ }^{3}$ While knowledge of God's existence, though needing to be revealed, is at least obtainable for human beings, knowledge and understanding of the Divine essence is absolutely impossible for any created being. Following the Cappadocians, it was unanimously accepted that there is

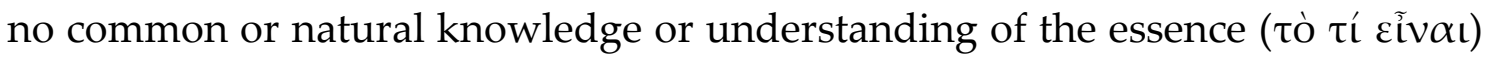
of God (Basil, Adv.Eun. 1.12). ${ }^{4}$

What God reveals to us about Himself, then, is not His essence and substance, which no created intellect can grasp - be it that of a human being or that possessed by any other kind of being capable of engaging in intellectual activity and receiving knowledge. What is revealed is knowledge not of God's essence, but of the Divine attributes, which should not be conceived of in terms of properties or accidents such as might variously be predicated of a substance. The attributes of the Divine essence refer instead to the actions and powers of God manifested through the Creation and ultimately revealed to us in the form of His only-begotten Son, Jesus Christ. In this way, our conception of God is made up of a multiplicity of attributes manifested and revealed to us, while any

${ }^{2}$ In this paper, the Cappadocian conception of religious language is given a systematic rather than purely historical treatment. I offer here some conclusions from, and further conceptual developments of, the analysis of that conception presented in my study "Logic and Religious Language", (Forthcoming) in The Routledge Companion to Early Christian Philosophy (2021).

${ }^{3}$ Cf. Diogenes Laertius, 10.123-24; Cicero, De natura deorum, 1.43-9, 2.12-13; Plutarch, De communibus notitiis adversus Stoicos, 1075e.2-7.

${ }^{4}$ The reason for this is that the Patristic authors assumed the Ancient philosophical position according to which our knowledge has to do with entities - i.e. substances, be they sensible or intelligible (forms, ideas, abstracta). See below. 
understanding of His essence as such nevertheless remains unattainable (Basil, Adv.Eun. 1.14; Ep. 234.1-3).

It is important to realize that none of the features deducible through analysis of God's powers and actions directed at the created realm, on the basis of which one forms one's idea and conception of God, suffice to disclose the Divine essence. Those powers and actions, though of a Divine origin, are situated within the created realm, and thus differ ontologically from their source. Characteristics ascribed to God on the basis of his actions either signify what He in essence is not (as uncreated, without beginning, incorporeal, etc.), or something related to His essence or operation (as good, creative, etc.) (cf. Basil, Adv.Eun. 1.10, 4).

To illustrate this, one may imagine a situation where, from within an enclosed cave or a cell, someone unknown and invisible is engaged in constantly exchanging artistically crafted objects for food and materials. Given that the cave or cell prevents one from knowing who is inside, there are a quite limited number of things that can be said about who they are. Certainly, one can assume that they exist, and are a living thing rather than a robototherwise they would not need food. It also can be assumed that they are creatively and artistically talented. Meanwhile, whether they are an actual human being or some sort of human-like being of celestial origin would seem to be a question of probabilities. Yet we cannot be at all sure whether they are female or male, what their origin or history might be, and so on. Indeed, we have no genuine rational basis for asserting anything with certitude as regards their substance, given that all we know is that "they" exist and are alive, and possess artistic gifts. After all, any such "artistic gifts" will not reveal their essence as such, pointing as they do only to some characteristics of their actions or fruits of their activities. In speaking of them as "artistically gifted," then, we are not asserting anything regarding their nature, but only naming one of features of their activities that happens to be known to us. Moreover, if one tries to construct a conception of what or who is behind the walls of such a cave or cell exclusively on the basis of features that have been cognitively apprehended, one will at best generate a context-sensitive construal that will be dependent on presuppositions that are in some way or other culturally or even psychologically specific. In other words, one will arrive at an idea that is much more revealing of the nature of the reflecting subject than it is of that of the hidden object of such reflection. Thus, in much the same way, it is neither the case that God's actions reveal His essence as such, nor the case that His essence can be equated with the sum of characteristics deducible through an analysis of His actions and powers. Rather, any attempt to reach a conception of His essence on the basis of an analysis of either characteristics ascribed to Him or ones entailed by preconceptions about His Divine nature already possessed by 
our intellect will amount to no more than a construction of God in our very own image-one limited by our own cognitive-intellectual abilities and culturally specific norms.

In the end, it turns out that humans can attain some kind of knowledge of God's attributes only from what God has revealed to them, granting them a revelation that conforms to their capacities and needs. Hence, it is impossible to know or understand anything about God qua God and his essence, even within the limits of what created beings are capable of, beyond what has been revealed by Him. The question then rightfully arises, namely what in that case can be properly said about God? Thus, the premises and presuppositions of any talk about God do need to be clearly explicated as well.

\section{The Logical Premises of Attribution, Predication and Speaking about God}

The fact that God is beyond our knowledge does not rule out all possibilities of attributing appellations to Him. For what is attributed does not refer directly to God or the Divine essence. What God reveals to humans are features of his own actions and powers, which, as revealed, are perceived by the human intellect. Afterwards, what is revealed is subjected to a process of analysis and comprehension. Intellect, reflecting on what it has received through revelation and/or learned from observation, constructs a conception of God that comprises His characteristics as discerned through and in our thoughts. Thus, such predicative appellations, which are assigned to those characteristics and used in reference to God, actually refer to our own thoughts and reflections pertaining to God's actions and powers, and not to any subject such as would transcend absolutely the intellectual capacities of all created beings.

It is as a consequence of intellectual reflection upon the actions and powers of God that one comes to understand both what cannot be ascribed to Him, and what can be attributed to Him properly and with due reverence. ${ }^{5}$ However, it is necessary to remember that "to be spoken of" is different from "to be" especially in a case such as this, where essential predication is ruled out as completely impossible. With essential predication-in which something is predicated about a subject, but not about that subject "as of something else" (i.e. as belonging, in turn, to something outside itself) - the very essence ( $\tau$ ò $\tau i ́)$ of a subject is revealed. This is because features predicated essentially of a certain subject are present in it as its logical parts. It is in this way, for instance, that humanity is predicated of a particular human being, such as Socrates - thus affirming the humanity of or in Socrates. ${ }^{6}$ In the case of God, though, there is no

\footnotetext{
${ }^{5}$ Gregory of Nyssa, Contra Eunomium [CE] II.136.7-10, 138-140, 157.4-158.1.

${ }^{6} \mathrm{I}$ am referring here to the principles of essential predication as set forth by Plotinus. See the following two crucial texts on essential predication: Enneades [Enn.] 6.1.3.16-19, 3.5.18-23. See
} 
essential predication, as He is addressed only using the names we give to the Divine activities revealed and manifested to human beings, and not by means of names given to the very subject of those activities. ${ }^{7}$

On the one hand, as was pointed out by Gregory of Nyssa, every appellation/name (e.g. "just", "imperishable") said of the Divine nature must be understood as if it were accompanied by the verb "is" - thus, "God is just," or "the Divine nature is imperishable," and so on. Otherwise, a name applied in some way to Him would be referring to nothing at all. Gregory's claim entails that each name pertaining to God amounts syntactically to a categorical proposition of classical logic, in which "God"/ "Divine essence" serves as the subject, accompanied by the copula "is." The latter connects the subject with a predicate such as "just," "imperishable," etc. On the other hand, categorical propositions can be used in any kind of predication, including of the essential sort that, as we have seen, are simply impossible in cases of speaking about God. Gregory therefore suggests that propositions of the form " $\mathrm{A}$ is $x$ " do not ascribe some feature $x$ directly to $\mathrm{A}$, but are rather verbal reports drawing their meaning from what is perceived about A. The copula "is" does not serve here to make a predicate a part of the very "account of being." Accordingly, what is said of God is no more than an extrinsic attribute. We only apprehend and ascribe attributes of His essence, which are not equivalent to His essence as such (C.Eun. III.5.57-59). Indeed, one could say that from the point of view of semantics, this is not a case of predication at all. And in fact, practically all major authors of the Greek and Latin tradition shy away from describing this

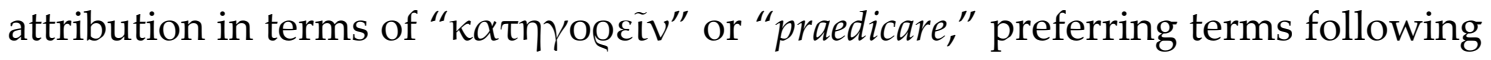
the model furnished by expressions such as " $\pi \varepsilon \varrho i ̀ ~ \Theta \varepsilon o \tilde{v} \lambda \varepsilon ́ \gamma \varepsilon \tau \alpha \iota$ " or "dicitur de Deo." 8

also Strange 1981, 158-70); cf. Gerson $(1994,89)$ and Owen $(1965,136)$. Essential predication was understood in this same way by Plotinus' Neoplatonic followers.

7 Gregory, CE II. 304.5-8; and John Damascene., Expositio fidei [Exp.], 9.7-9, 10.7-16. As with Basil, according to Gregory, names applied to God fall under two categories: affirmative appellations and appellations in the form of negation (see Adversus Eunomium [Adv. Eun.], II.131-6, 142-6). The same idea is expressed in John Damascene, Exp. 9.7-9, 22-29. I refrain here from discussing the difference between those two forms of appellation.

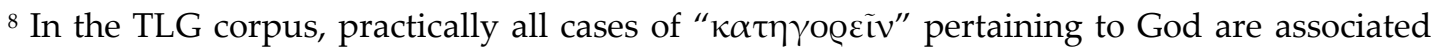
with God's being unjustly accused of something. The only exception I have been able to find is the Trinitological claim in Gregory of Nyssa's Ad Graec. 3.1, 28.17-21. Gregory says there that the Trinity is not three individual hypostases, as in humans, of which "God" would then be essentially predicated. In such Latin authors as Aquinas, in turn, examples of "dicitur de Deo" are countless, while a quick search in, for instance, Index Thomisticus (http://www.corpusthomisticum.org), points to just 37 instances of "praedicatur de Deo" and its variants. In the majority of those cases, Aquinas is responding to a difficulty by trying to show the conditions under which a variant of predication could pertain to God. For instance, in Super Sent., lib. 1 d. 22 q. 1 a. 2 arg. 2., he says that referring names of creatures to God "is not true 
To make sense of this distinction, it seems necessary to go back to and examine the Eunomian controversy, and the philosophy that stood behind it. The idea that the names deployed when speaking about God do not signify His very essence, but rather His attributes/characteristics as revealed through His actions towards the created realm and human beings, had been inherited from Judaic thought and pretty much accepted right from the very beginning of Christian theological discourse. ${ }^{9}$ However, the question of the very possibility of predicating things of an object that was both unknown and impervious to cognition or apprehension by the human mind, and of the rules and criteria for any such predication, did not arise prior to the Eunomian controversy.

Along with other lines of argumentation, Eunomius' questionable Trinitarian claims of Arian provenance were supported by his understanding of human language generally, and the nature of linguistic reference in particular. Given that numerous Christian writers accused him of being overly influenced by pagan philosophy, especially in regard to his account of language, it is worth asking what the philosophical conceptions were that he made use of when seeking to substantiate his theological claims. To be sure, at first sight, it might seem that Eunomius accepted a quite simplistic view, according to which there is a direct correspondence between names and the subjects of which they are said. ${ }^{10}$ This simplistic account of the relationship between words and things is, moreover, often erroneously ascribed to Greek philosophical thought in general.

In this regard, it has to be acknowledged that it is rather difficult to speak of there having been any comprehensive theory of language - at least as we would understand this today-in Greek and Hellenistic philosophical thought, either before or after the Eunomian controversy. However, this should not be taken to mean that the real core issue, which in my opinion is that of reference, had not already been confronted at the earliest stages of the formation of philosophical

predication," while in Super Sent., lib. 1 d. 8 q. 4 a. 3 co. he characterizes it, following PseudoDionysius, as "predicating in the mode of eminence." Unfortunately, in many current translations this important metalogical distinction has been overlooked, with tragic consequences.

9 Aristides, Apologia, 2.1 Syr. (SChr 470: 184-6 Pouderon / Pierre); Justinus Martyr, Apologia secunda pro Christianis ad senatum Romanum 5.1.1-2; Theophilus, Ad Autolicum, 1.3.2-12. Cf. van den Broek (1988); Dillon (1988). See also the study of Philo's account of naming the Divine and its connections with early Christian thought in Runia (1988).

${ }^{10}$ It should be pointed out that in the present paper, Eunomius' claims are shown through a focus on his philosophical, and in particular his semantic, presuppositions. Accordingly, attention is given to the logical consequences that follow from adopting presuppositions of this kind within theological discourse. For a more general and theological take on the issue, see DelCogliano, (2010, 38-95). In that work, the philosophical constituent of Eunomius' account is held to be one of the "sources" of his theory. See also note 25 below. 
thought as such. In contrast to the widely entertained view that holds that the thinkers of Antiquity simply took for granted the idea of our language representing reality and the names we employ referring quite naturally to their subjects, this simply was not the case. Plato, in his Cratylus, had already attempted to investigate topics such as the meaning and function of names, as well as the issue of how they refer to what they name. In his view, names are tools through which we learn about things that exist. It is through names that we learn how to distinguish between things that differ in respect of their essence. To be sure, they are conventional, yet Plato postulated that such conventional names be fixed by a perfect "name-giver" or "law-giver"

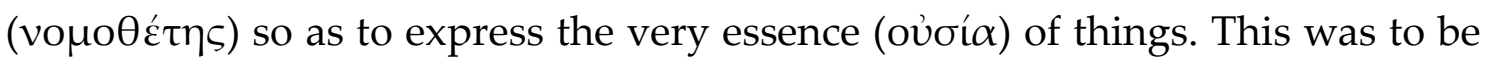
achieved by them through imitation of the essence and species/form (the

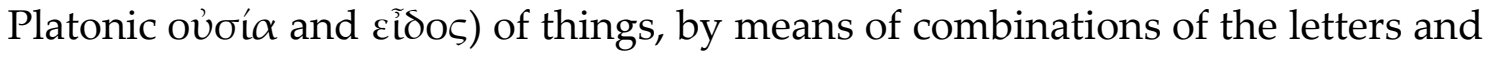
syllables that constitute names. At the same time, Plato himself recognized this theory to be strange, and even a little ridiculous. ${ }^{11}$ Yet, in the Sophist, he sought to explain the premises on which his views rested. He stated clearly that a name could not lack a subject of reference: naming ought to refer to something different from itself, if such a function was to have any sense at all, and so he denied that a name and its subject could be identical (Soph. 244d 6-9). On the

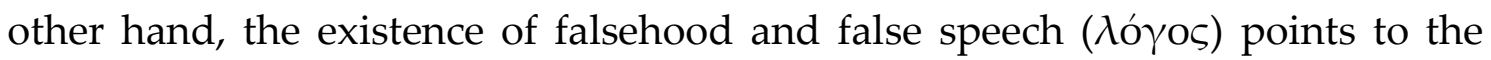
fact that truth arises only when names are properly connected to the appropriate predications or verbs. The logos, in the sense of a complete act of speech, is a composition of name(s) and verb(s), and such a composition might be seen as revealing or concealing the truth (Soph. 261 D-263 D). He identified

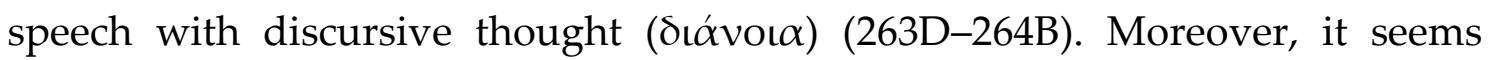
reasonable to regard Aristotle's theory of categories and the Stoics' conception of "complete sayables" as being to some extent two different ways of developing those intuitions.

In Aristotle, sensible substance is the proper subject for assertions of real existence or ascriptions which presuppose real existence. Anything that is said is predicated of sensible primary substances. Thus, predication (the exact rendering of the Greek word kategoria) consists in attributing to a primary substance a predicate in the category of substance or of any one of nine other categories. According to Aristotle himself, these much-famed ten categories corresponded to that which is said without any combination, and they signified substance, quality, quantity, etc. As such, they could not themselves be deemed true or false. Yet Aristotle stressed that through combining these with one another we produce an affirmation that can be true or false (Cat. 1b25-2a10). To 440 .

11 We see the theory in question being gradually constructed over the course of Cratylus 388- 
be sure, he did claim that names, as spoken sounds or written symbols, are significant by convention, and that they correspond to thoughts or mental states construed as likenesses of existing entities (De Interpretatione 16a3-26). Nevertheless, those mental states, or acts of thinking, seem to be copies of the things they are likenesses of. Thus, it is possible to say that Aristotle maintained that names refer to and signify things ( $\tau$ ò $\pi \rho \tilde{\alpha} \gamma \mu \alpha$ ), albeit through the intermediary of their likenesses in the mind (cf. Top. 108a18-22).

An important refinement to this Aristotelian account of meaning was furnished by the categorical theory of Porphyry, who built on Plotinus' critique of metaphysical interpretations of categories as genera of being. Plotinus had shown that a philosophically coherent reading of Aristotle's categorial theory requires that the categories be seen as classifications of denominations ascribed to sensible objects, through which, moreover, the latter are comprehended. In Porphyry, the issue of relations of names to things is raised via the theoretical question of what Aristotelian categories are in themselves. In the course of furnishing an answer to that question, Porphyry proposed a theory setting out the relationship of names to things, rules of predication, and relations between these and what we would now call a metalanguage-in which a descriptive account was offered of predication within the framework of the categories. This theory has come to be known as that of the "first/second supposition" of expressions ( $\theta \dot{\varepsilon} \sigma \iota \varsigma$, also rendered by scholars of Ancient philosophy as "imposition"). According to it, expressions of first and second supposition designate, respectively, objects and words (Porphyrius, in Cat. 57. 22-58). The idea is that expressions belonging to a given category are expressions of first imposition: i.e. they are nothing else but expressions signifying things. ${ }^{12}$ The categories, and the predications belonging to any given category, are applied to the subjects of which they are predicated not directly, but rather through the mediation of so-called "non-integrated" or "unranged" genera, which themselves may be treated as generic concepts pertaining to things. ${ }^{13}$

Given the fact that the logical apparatus available to Christian authors of the Patristic era was the Porphyrian (logical) interpretation of Aristotelian categorical doctrine, their scruples regarding the attribution of appellations to

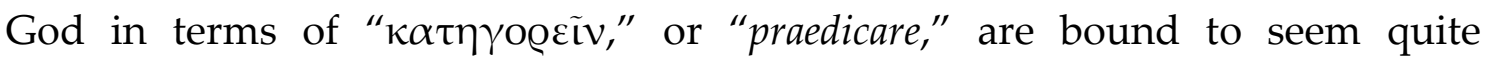
understandable. The point is that Porphyry's idea of predication necessarily implies the accessibility of things/objects of predication to knowledge and perception. He understood predication as the uttering of a significative

12 Porphyrius, in Cat 56.8-9; 58.3-6; 70.25-29; 71.1-14.

${ }^{13}$ Dexippus, in Cat. 10.25-32; Simplicius, in Cat. 13.11-18. Simplicius claims that this opinion was also accepted by Alexander, Herminus, Boethius, Iamblichus Syrianus and his teachers (probably Ammonius and Damascius). See Zhyrkova (2008, 258-63); Ebbesen $(1981,152)$ and Lloyd (1990, 62ff). 
expression about certain things ( $\kappa \alpha \tau \dot{\alpha} \pi \varrho \alpha \gamma \mu \alpha \dot{\tau} \omega \nu)$, and accepted only two types of supposition: expressions of first supposition ( $\tau \tilde{\eta} \varsigma \pi \varrho \omega \tau \eta \varsigma \tilde{\eta} \nu \theta \varepsilon \dot{\varepsilon} \sigma \omega \varsigma$ ), meaning those said of things, and expressions of second supposition ( $\tau \tilde{\eta} \varsigma$ $\delta \varepsilon v \tau \varepsilon \dot{0} \alpha \varsigma \theta \varepsilon \dot{\sigma \varepsilon} \omega \varsigma)$, understood as those said of expressions themselves. ${ }^{14}$ In line with this distinction, anything ostensibly said about God according to the first supposition cannot be treated as an essential predication, or any kind of predication sensu stricto, as there is no direct subject of predication accessible to our understanding, knowledge or perception. Even if one adheres here to the much more developed medieval account of signification and supposition, this will not make any real difference. To be sure, a significant expression can stand for (supponit pro) either itself (material supposition) or its form or concept (simple supposition)-or for things/items that it signifies through forms/concepts (personal supposition). Thus, it might well seem that what is said about God (i.e. that "God is XYZ") is predicated of Him according to socalled simple supposition, in that predicative appellations, which are used in reference to God, refer to our own thoughts and reflections pertaining to God's actions and powers; however, an account of attribution and predication framed in terms of any kind of theory of suppositions, be it medieval or later, presupposes that a predicate/name stands for a thing (supponit pro aliquo). In the case of simple supposition, what is implied is that there is a universal mental concept of God qua God (just as we have a universal concept of what a dog or a cat is), whereas-as was pointed out by St. Basil-human beings are not themselves in possession of any common conception of God and His Divine essence. Otherwise, all people would have the same conception of God, just as we all have an identical conception of what, for instance, a cat or a dog is (Adv. Eun. 1.12, 1.5). Instead, our conception of God is made up of many attributes manifested and revealed to us through His actions and powers, even while an understanding of God qua God, and of His substance as such, remains unattainable (Adv. Eun. 1.14; Ep. 234.1-3). In other words, names and appellations used in reference to God express how we conceptualize God's actions and powers towards us, and not God himself. Therefore, in the case of God, the very "aliquid" for which the appellation/name/predication stands in either personal or simple supposition is actually not God, but His actions and powers. Still, the fact that God, as a subject of predication, lies beyond our knowledge, does not contradict the very possibility of speaking about Him in terms of what is revealed by His actions and powers, and an explanation of how this could be possible was given by Basil using the Stoic account of

${ }^{14}$ See Stan Ebbesen's reconstruction of Porphyry's account of first and second impositions, which goes significantly beyond the limited sources available to us, elucidating Porphyry's conception in terms close to those developed in Latin Medieval philosophy. See Ebbesen (1981, 141-58). 
signification as its basis.

Where relations between names and the things signified by them are concerned, the Stoics differentiated between three items that, in their opinion,

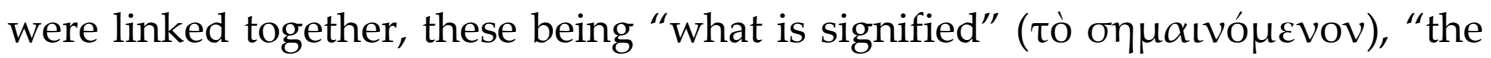

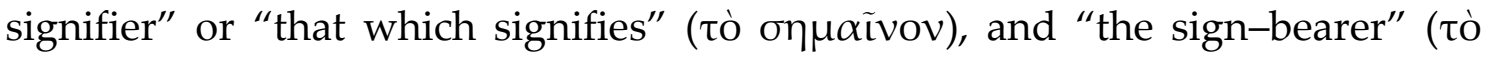
$\tau v \gamma \chi \alpha \dot{v o v})$. Not unsurprisingly, the signifier is an utterance ( $\varphi \omega v \eta \dot{)})$, while the name-bearer is an external object. However, the utterance does not signify the external object, even though the utterance refers to it. What the signifier (i.e. the

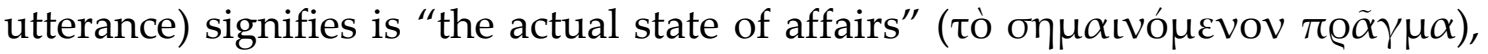
where this would appear to correspond to the Stoics' much-famed "sayables" ( $\tau \dot{\alpha} \lambda \varepsilon \kappa \tau \alpha) .{ }^{15}$ Sayables belong to the classes of incorporeals that, in spite of having some kind of subsistence and being an ineliminable part of the objective structure of the world, do not exist in any proper sense. ${ }^{16}$ They can be interpreted as intentional objects of thought conveying impressions of material objects. At the same time, human speech itself only serves to reveal what is presented by just such lekta. In other words, names/utterances/predications signify the latter, and it is only through these that they refer to real material entities. ${ }^{17}$ Since it is the lekta that count as rational representations of physical/material objects, it is they, and not utterances predicated of a subject, that can be seen as true or false. ${ }^{18}$ Moreover, the Stoics were prepared to accept as a criterion of truth the presence of a cognitive impression that necessarily had a real object as its cause and also necessarily represented this object with complete accuracy and clarity. ${ }^{19}$ This vision of the relationship between words and things played a crucial role in Basil the Great's answer to Eunomius.

In Eunomius' works, which elicited a strong reaction from Basil the Great, particular notions and items of philosophical vocabulary belonging to different philosophical traditions were incorporated into a fairly eclectic view as regards language itself. ${ }^{20}$ Eunomius embraced the idea of God as the source of human knowledge of things and language-one that is traceable back to Plato's

${ }^{15}$ Sextus Empiricus, Adversus Mathematicos [adv. Math.] 8. 11-12 (SVF 2.166)

${ }^{16}$ Sextus Emp., adv. Math. 10.218 (SVF 2.331), 8.70 (SVF II.187), 8.409-10 (SVF II.85).

${ }_{17}$ Sextus Emp., adv. Math. 8.70; Diogenes Laert. VII 63; 57. Concerning the question of lekta and their function in language, as well as differences between Aristotle's and the Stoics' accounts, see Long (1971, 75-90) also Long and Sedley (1987, 195-202).

${ }^{18}$ Sextus Emp., adv. Math. 8.11.

${ }_{19}$ Diogenes Laert., 7.54 (SVF 2.105, Posidonius, fr. 42); 7.46 (SVF 2.53); Sextus Emp., adv. Math. 7.253-60; Cicero Acad. 2.77-8. Long (1971, 91-106); Sandbach (1971) also Long and Sedley (1987, 241-53).

${ }^{20}$ For a concise and comprehensive description of the history of the search for the philosophical roots of Eunomius' conception, see Karfíková (2007, 294-9). 
"name-giver" and its subsequent interpretation within the Platonic tradition. ${ }^{21}$ He also accepted the notion of words' referring directly to their subjects, as known to him from Aristotle's system. ${ }^{22}$ What is more important, though, is that he also had recourse to Stoic ideas to the effect that names referred via, and in terms consistent with-or "on the account of"-human intellectual reflection ( $\kappa \alpha \tau^{\prime} \dot{\varepsilon} \tau_{i}$ vol $\left.\alpha v\right)$ concerning our natural conceptions of things. That is to say, while understanding the Stoic conception of the reference of what is said ( $\tau \dot{\alpha}$ $\lambda \varepsilon \gamma o ́ \mu \varepsilon v \alpha$ ) in a highly narrowed and-according to Basil-erroneous manner, he rejected the view that names, and amongst these the names of God, are used "on the account of human thought," arguing instead that they are attributed to God "on the account of" His very essence. ${ }^{23}$ In Eunomius, the names/expressions of human language do not express results of intellectual reflection on some conception or other, but rather seem to disclose the very conception ( $\left.\varepsilon^{\prime} v{ }^{\prime} v i \alpha\right)$ itself of the subject named by the relevant expression. ${ }^{24}$ Moreover, it seems that on the basis of the Stoic idea of conceptions ("zvvot $\alpha$ ) and natural conceptions ( $\varphi v \sigma \iota \kappa \eta \dot{\varepsilon} v v o t \alpha$ ), according to which the human intellect possesses conceptions both of the things of which it has received impressions and of their natures, Eunomius claimed that human beings are endowed with a natural conception of God: that $\mathrm{He}$ is one, and also unbegotten. ${ }^{25}$ Indeed, Eunomius believed that these natural conceptions are imposed on us by God Himself. He therefore asserted that since the human intellect had been granted knowledge and proper appellations of both God and created things by God himself, one could apply proper appellations and names to God and His Divine essence after all.

${ }^{21}$ Eunomius, Apologia apologiae [Apol.] II ii (J 282.1-14; J 346.20-347.1) II.VI. (J 386.5-7); II i (303.1-6) see Vaggione 1976, 173-4; 227-8.

${ }^{22}$ Eunomius, Apol. 18.7-9; 12.7-11.

${ }^{23}$ See Eunomius, Apol. 8.1-5, cf. Demetracopoulos (2007, 387-9), who claims that Eunomius does not in fact reject conceiving God through epinoia out of hand, but finds it inadequate.

${ }^{24}$ Eunomius, Liber apologeticus [Lib. apol.] 18.4-7; Apol. II, v J 368.6-18; III (J ii 168.11-12).

${ }^{25}$ Eunomius, Lib. Apol. 7, 7.1-3. Some of the philosophical influences on Eunomius' account were explored in DelCogliano (2010), who basically traced them back to Plato's Cratylus while nevertheless entirely ignoring his quite visible, and sometimes direct, dependence on Stoic semantics in particular. Even so, when considering Basil's criticism, DelCogliano acknowledges Eunomius' knowledge and usage of at least one of the Stoic conceptions: namely, that of common/natural notions (see p. 156). Cf. also Mortley (1986, 135-6), who thinks that Basil rejects Eunomius' conception of ennoia for the reason that Eunomius' view of ennoia is reductive, limiting ennoia to a narrowly philosophical meaning. Mortley's interpretation of both Eunomius' account and Basils' response neglects the patent references, especially in the latter, to Stoic theory of knowledge and language. This leads Mortley to read Eunomius's account as founded on Platonic and Neoplatonic premises, and Basil's response as essentially nonphilosophical. 
Leaving aside questions pertaining to the analysis of Eunomius' various misconstruals of Stoic thinking as already pointed out-quite accurately-by Basil, we need to draw attention to the main problem of his theoretical position: this is that from a philosophical point of view, to say that one is endowed (either by God or by nature) with a certain conception-e.g. an ennoia- of Man, presupposes that one is in a position to state correctly what Man is. ${ }^{26}$ For possessing a common or natural ennoia of a given thing entails a full and complete comprehension of this thing. ${ }^{27}$ In other words, to assert that the human intellect has been endowed with a conception of God-even if it be one provided by God himself - is to claim that human beings know and understand what God is in regard to His very essence. ${ }^{28}$ And this was something neither Basil nor his brother Gregory could ever have concurred with.

Responding to Eunomius, Basil turned to the already mentioned ideas of epinoia and kat' epinoian. ${ }^{29}$ However, he did so not in the simplified version of

\footnotetext{
${ }^{26}$ Sextus Emp., adv. Math. 11.8.

27 Cicero, Academica Post., 21; Tusculan disputations, IV, 53. Cf. Long and Sedley (1988, 239-
} 53).

${ }^{28}$ It is hardly surprising, then, that he was accused of claiming that he knew the Divine Essence perfectly. See Eunomius, fr. II (Vaggione 167-170), i.e. Socrates Scholasticus, Historia Ecclesiastica IV.7; Theodoret, Haer. IV.3. An explication of Eunomius' stance through his statement that knowing need not necessarily involve complete understanding (Vaggione 1976, 278) would only imply that Eunomius in fact had no real grasp of the philosophical vocabulary he was employing (or its proper usage). Attempting to explain Eunomius' views by invoking different theological perspectives (for instance, a soteriological one, as in Wiles (1989, 157-172)) does not enable one to entirely dismiss the conclusions entailed by Eunomius' employment of philosophical conceptions and vocabulary. I would like to stress that such an interpretation of Eunomius' views follows logically from an analysis of his own statements.

${ }^{29}$ Once again, I would like to point out that I am only concentrating here on the aspect of Basil's critique of Eunomius' views most relevant to the present study. For discussion of other, theological aspects of his critique, see DelCogliano (2010, 135-152). In that very same work, DelCogliano (to some extent following, and building on, the study of Radde-Gallwitz (2009, 143-174)) also discusses in much detail Basil's theory of names, which he designates - using a quite specific expression - as "the notionalist theory of names." According to the latter theory, which DelCogliano attributes to Basil, "each name has a distinct meaning, which is to say a distinct notion ( $\varepsilon^{\prime} v$ vor $\alpha$ ) associated with it, a notion which holds true of both God and mundane realities" (p. 153). Although DelCogliano makes many valid points on the issue, he fails in my opinion to observe Basil's quite clear knowledge and employment of the Stoic theory of language - and this despite the fact that DelCogliano indeed recognizes Basil's appeal to such Stoic ideas as "common/natural notions (ennoiai)" and "common preconceptions (prolepseis)" (see p. 156-7). This neglect of significantly Stoic elements in Basil's thought brings DelCogliano, among many others, to two conclusions with which I cannot bring myself to agree, even though I would accept his theological analyses en globe. First of all, I find DelCogliano's claim that, for Basil, there is a one-to-one correspondence between names and their notions, to be quite a simplification. Without grounding human notions and intellectual reflection in sensationswhich, after all, are caused by real things (be it a stone, or even the revelatory activity of God) - 
Eunomius, but rather in terms consistent with how these had been elucidated by the Stoic Chrysippus. In Chrysippus, what is comprehended kat' epinoiani.e. "on the account of thought" - is based on experience and perception of the relevant reality, and is grasped either through resemblances to things presented in experience or by an enlargement, diminution, or composition thereof. ${ }^{30}$ In turn, in Basil, غ̇ंívot $\alpha$ refers to a more detailed and precise consideration of what has already come to be known intellectually: one which comes after the initial conception (nоёma) emerging from sensation. In other words, it is a reconceptualization (ep-ennoia) of our grasp (i.e. our conceptions) of existing things-both those possessed naturally and those received via perceptionthrough which an intellectual analysis and/or understanding of different

those notions will be baseless, and prone to fallacy and heretical errors, too. The second conclusion with which I disagree is that, according to DelCogliano, the possible source for Basil's theory of names was the Neoplatonic interpretation of Aristotle set forth by Porphyry and Dexippus. In this, DelCogliano comes close to Radde-Gallwitz.

I should remark at this juncture that it is hard to come up with counter-arguments to analyses in which speculations about possible sources based merely on terminological similarities are entertained, and where this betokens ignorance of an important piece of ancient philosophy. Unfortunately, Stoicism is all too frequently considered an arcane subject, of interest only to the specialist and so something one may seemingly neglect in the context of ecclesiastical education without damaging consequences-especially in that its physical theory was rejected by the Fathers themselves. This avoidance of explicit references to the Stoics by the latter, however, makes many scholars of Patristics blind to those cases in which they rely on Stoic logic, as well as prompting a lack of interest on their part in the revival of scholarship relating to Stoicism that has occurred in the last 30 years or so. Recently published or reedited Stoic manuscripts, including texts important for the study of logic, are similarly ignored. Instead, just because the very same terms (e.g. "name" or "ennoia") show up in both Stoic and Neoplatonic logical discussions - on account of the fact that the Neoplatonists did, indeed, read the Stoics, and both schools did, indeed, grow out of attempts to solve the problems raised by Plato-Patristic scholars frequently label all logical considerations arising in the writings of the Fathers as "Neoplatonic." It does not, apparently, matter whether those considerations follow the rationale of Neoplatonic semantics, or that of Stoic semantics, even though these differ deeply, especially in respect of their respective views on how meanings are formed and what kind of cognition is reflected in them.

In Basil-unlike in the case of Gregory of Nyssa-it is very difficult to furnish any kind of evidence of Neoplatonic influence. Notably, DelCogliano himself concedes its visible absence. What he overlooks is the very strong evidence of Basil's reliance on Stoic philosophy in general and, more particularly, in respect of the issue presently under discussion, as I will be showing in due course here. The very philosophical vocabulary employed by Basil speaks extremely powerfully to us of its Stoic origins. Furthermore, Basil does not deploy the Neoplatonic semantic terminology that relies on and assumes uniquely Neoplatonic conceptions of signification and predication. In any case, my view is that the interpretation of Basil via an appeal to the Stoic conception of language put forward in the present paper need not entail a rejection of the main theological conclusions arrived at by DelCogliano and Radde-Gallwitz; rather, it actually could make them even stronger.

${ }^{30}$ Chrysipppus, fr. 88; Sextus Emp., adv. Math. 8.58-60. 
aspects of the thing under consideration is achieved (Adversus Eunomium [Adv. Eun.] I.6). ${ }^{31}$

Basil held that the expressions of human language do not refer to their subjects directly, but instead do so "on the account of" intellectual reflection, even though he accepts that names of things are posterior to things themselves (Adv. Eun. 2.4). ${ }^{32}$ Meaningful expressions are vehicles for human reflection by means of which we communicate (Homilia in illud 23). That is to say, conveying the meaning that emerges through acts of reflecting on perceived and cognized things, they refer to the results of our intellectual acts and not directly to the things themselves. According to Basil, names and appellations neither refer to things directly nor signify their essences; instead, they signify the properties that characterize particular things. In the case of entities belonging to the created realm, any conception of this or that thing of which we have received an impression will pertain to those properties that have been observed in regard to that particular thing (Adv. Eun. 2.4). Furthermore, it is in precisely this respect that the attribution of names and appellations to God turns out to be different. Yet even so, this difference is subtle and, moreover, easily overlooked. In the case of created entities, the initial conception of a thing results from a sensation of the thing itself, so the conceptualization of it communicated through meaningful expressions (names and appellations) still pertains to the thing itself. Hence, names and appellations, while signifying the properties that characterize this or that particular thing and not its very essence, still refer to a thing, albeit indirectly. But where God is concerned, our initial conception of him results merely from our perception and experience of His actions and powers. Therefore, our conceptualization of this initial grasp of God that we have does not reflect God qua God or His substance. And the appellations we attribute to God consequently only express various manifestations of His benefactory engagement with created reality, of the sort conceptualized in thought processes antecedent to any verbalization. ${ }^{33}$

If one adopts the Stoic account of signification that seems to be presupposed in Basil and that also came to be employed by, amongst others, Roland Barthes in his Éléments de sémiologie, then the situation can be explained in the following

${ }^{31}$ Cf. Chrysippus, fr. 88, 9, 404, 501. In my opinion, Basil's elucidation can be traced to the account of Chrysippus, but this issue calls for a more in-depth study. Also, it is worth noting that John Damascene, in basically transmitting Basil's account of epinoia, refers to it as ep-ennoia: i.e., as to something adding to an ennoia (Dialectica 65.84-5). See also Demetracopoulos (2007, 390-91), where he argues that Basil draws on a lost logical part of Arius Didymus' Epitome, and Demetracopoulos (1999), where he shows some parallels with Plotinus' usage of the Stoic conception of epinoia. Also Karfíková (2007, 299-300).

32 Cf. also Meredith (2007).

${ }^{33}$ Contra Scott $(2013,17)$, who interprets the language of Cappadocian "positive theology" as being directly representational and naturalistic. 
terms. Any appellation recognized as proper with respect to its being used in reference to God (no matter whether it be something along the lines of "the Good is the Just," or even "God is the Father") can be seen as a signifier (in Barthes' terminology, "le Signifiant") that relates to "what is signified" (in Barthes' terminology, "le signifié"). The latter corresponds not to "the sign-

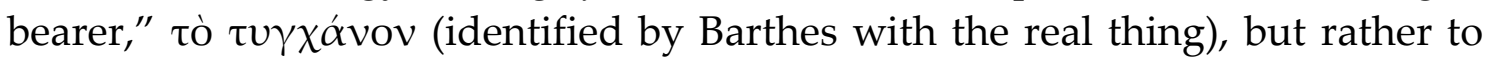
the Stoic lekton / $\lambda \varepsilon \kappa \tau o ́ v$, which is as much as to say to an intentional object. ${ }^{34}$ Normally, this intentional object is a linguistic reality. It is within this reality that elements of our experience are abstracted, and, in a way, "standardized" within the system of meanings of a given language. (This process of standardization of meanings in a system of meanings based on primary oppositions can be treated as the equivalent of Basil's "intellectual reflection.") When those elements are recombined in a sentence in which a feature is predicated of a subject, what is spoken about (i.e. the bearer of such features) can be recognized by the person to whom the sentences are addressed thanks to the latter's experience and knowledge of the correspondences between meanings and things. This bearer of features, the "sign-bearer" of the entire sentence, can be unproblematically picked out, as it corresponds to the name of the subject of the sentence. Yet if we examine sentences in which something is said about God in the light of this same model of communication, we realize that while le signifié (the signified) conveys our impressions of God's powers and actions, the sentence as a whole does not point to any "sign-bearer" in the actual reality we are experiencing: in such a sentence the signifier "God" amounts to an empty support, devoid of its own "signifié." The only "signifié" that can be attributed to it will be one based on our impressions of what we take to be God's actions and the expressions of His powers. A sentence such as "God is merciful" therefore points to a "signifie" whose meaningful content is identical with that of "merciful."

The sign-bearer of this sentence is something envisaged by those who pronounce it, not something encountered as " $\tau v \gamma \chi \alpha \dot{\alpha} v v^{\prime}$ " in the sense, literally, of "something falling under" an act of speech. The very name "God" is devoid of any other signification by itself, but since it is used in a sentence, it is a name in search of its bearer, with expressions such as "merciful" or "all-powerful" just indicating the direction that that search might take. In consequence, no essential characteristic can be attributed to the name-bearer of the subject of such a sentence on the basis of either that sentence itself or any other similar assertion. Returning once more to the logic of signification and predication, one can say, of all of the appellations used in reference to God, that they do not

\footnotetext{
${ }^{34}$ Barthes (1964, 107).
} 
denote Him or His essence, and cannot be predicated of Him in respect of His essence. Certainly, for the very reason that the source and justification for any such attribution remains the Divine revelatory activity itself, our non-essential attribution testifies in truth to what belongs to God (Adv.Eun. 1.7), but the fact remains that God, being beyond any knowledge and understanding on the part of created intellects, cannot be treated as a subject of predication in essence.

\section{Conclusions}

Examining the way in which the Cappadocians tried to express the mystery of the Trinity, and considering also the form of Conciliar Trinitarian statements, in which the Trinity seems to be characterized positively in terms of one substance and three hypostases, one may receive the impression that in the context of Trinitarian concerns none of the above-mentioned epistemological and logical premises are in fact relevant. For it seems, indeed, that the very essence of God is expressed after all through those notions of substance/nature and hypostasis/person which appear to be used as predications. ${ }^{35}$ And to this we might add that the very inner life of the one Divinity-i.e. being Father, Son and Holy Spirit-is itself a subject of revelation. As something revealed, this truth, though in itself a mystery that cannot be comprehended and explained by any created intellect, becomes a subject of reflection, due to the very fact that its revelation has been necessarily transmitted in and through human language. In this reflection on the Trinity, however, what is (for some reason or other) so easily forgotten is that this is not in actuality different from Divinity, but rather identical with the latter-in spite of any differences with respect to the names for these or the meanings they convey. Thus, if it has been accepted that one may speak about the Divine as something above and beyond any created essence and substance, then the same custom ought certainly to be adhered to where the Trinity is concerned, as well: when engaging in Trinitarian discourse one should keep in mind that the Holy Trinity is itself something above and beyond substance. ${ }^{36}$

The main problem, then, is this: the revealed truth about the Triune God gives us a truly mysterious insight into the very reality of the Divine essence, where the latter, as was stated above, lies absolutely beyond all human capacities of understanding. What is more, the issue of His essence is not one that can be addressed using appellations, given that these can only be correctly

35 See passim in Letter 38, in Ad Ablabium, as well as in Ad Graecos; see also Edwards (2016, 61-74); Zhyrkova (2019).

${ }^{36}$ Much to my surprise, I have found that Leontius of Jerusalem is the only one who speaks about the Holy Trinity in terms of hyperousios. See Leontius of Jerusalem, Contra Nestorianos IV.26, PG86, 1689B. 
applied to God when employed to refer to His actions and powers, and not who $\mathrm{He}$ is in regard to His essence. But when anyone says that the Divinity/God is one substance in three hypostases, this will be precisely a case of so-called "predication in essence." To forget about Gregory of Nyssa's claim that anything said about God is no more than a verbal report of what has been unveiled to us and does not reveal the very account of His being is to commit a mistake not at all unlike the Eunomian heresy condemned at the First Council of Constantinople. For someone holding that notions construed by the human mind (e.g. substance, nature, hypostasis, or person) can be applied simply and directly to the Trinity, and that these can also subsequently be employed in logical arguments that themselves rely on rules of predication reflecting our common-sense view of how things and their properties relate to one another, certainly adheres to the Eunomian heterodoxy. Such a person is accepting that there are things which can be known, understood and attributed to God in regard to His essence. In other words, they do not see the Triune God as different from creation, in that they are unthinkingly applying to God meanings and rules that have been derived from language employed for the purpose of describing the created realm.

It is undoubtedly the case that the Trinitarian proclamations of the Ecumenical Councils rejected the unorthodox doctrine and established a set of criteria for expressing the theological truth of the mystery of the Trinity. Moreover, as was stated at the very outset, Trinitarian theology should certainly evolve within the boundaries set by those criteria, adhering all the while to the direction laid out in conciliar theological decisions. Nevertheless, questions remain. For example, how can Trinitarian conciliar doctrines be properly elucidated, and what in fact can be said about the Trinity, given such strongly defined presuppositions concerning the possibility of knowing and speaking about God's essence? And does this mean that within the limits of Cappadocian theology, on which Conciliar Trinitarianism was built, there is no solution other than to just accept Trinitarian formulae such as adhere to an apophatic or Augustinian approach to the doctrine of the Trinity-simply admitting this as an article of faith and, at best, invoking the teaching of Vestigia Trinitatis? My own humble response to this would be to say that a positive and/or speculative vision of the Trinity, such as would be in agreement with Church Tradition as professed by the Councils, can indeed be constructed. However, it would involve (1) abandoning all treatment of Divinity in terms of essence, and (2) turning, in consequence of this, to the most fundamental

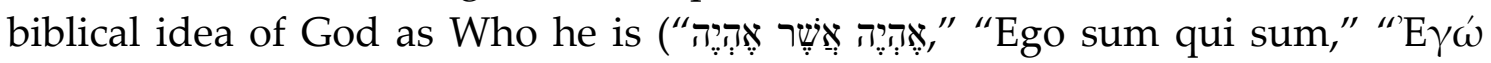

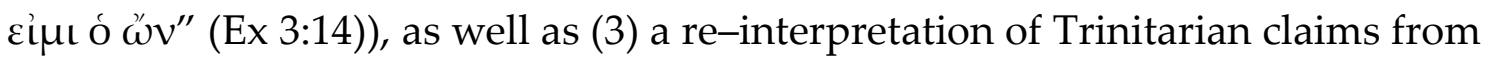
the standpoint of Christology and the conceptions developed within the latter, given that it is in Christ that God reveals himself fully and completely, and it is 
only through and in Christ that we understand who God is and that He is the Triune God.

\section{Bibliography}

Barthes, Roland. 1964. "Éléments de sémiologie." In "Recherches sémiologiques," Communications (4): 91-135. Reprinted subsequently in many collections of Barthes' works. https://doi.org/10.3406/comm.1964.1029.

DelCogliano, Mark. 2010. Basil of Caesarea's anti-Eunomian theory of names: Christian theology and late-antique philosophy in the fourth century trinitarian controversy. Supplements to Vigiliae Christianae: texts and studies of early Christian life and language 103. Leiden; Boston: Brill. https://doi.org/10.1163/ej.9789004183322.i-302.

Demetracopoulos, John A. 1999. "The Sources of Content and Use of epinoia in Basil of Caesarea's Adversus Eunomium I: Stoicism and Plotinus." Buzantina 20: 7-42.

Demetracopoulos, John A. 2007. “Glossogony or epistemology? Eunomius of Cyzicus' and Basil of Caesarea's Stoic concept of epinoia and its misrepresentation by Gregory of Nyssa." In Gregory of Nyssa, Contra Eunomium II : an English version with supporting studies : proceedings of the 10th International Colloquium on Gregory of Nyssa (Olomouc, September 15-18, 2004). Supplements to Vigiliae Christianae,, edited by J. den Boeft, J. van Oort, . L. Petersen, D.T. Runia, C. Scholten and J.C.M. van Winden, 387-97. Leiden ; Boston: Brill. https://doi.org/10.1163/ej.9789004155183.i-554.77.

Dillon, John. 1988. "The Knowledge of God in Origen." In Knowledge of God in the Graeco-Roman World, edited by R. Van Den Broek, Tjitze Baarda and Jaap Mansfeld, 219-28. Etudes Préliminaires Aux Religions Orientales Dans L'Empire Romain 112. Leiden: Brill.

Ebbesen, Sten. 1981. "Commentators and commentaries on Aristotle's Sophistici elenchi: a study of post-Aristotelian ancient and medieval writings on fallacies." Thesis doctoral - K'benhavns Universitet, E.J. Brill.

Edwards, Mark. 2016. "Porphyry and Cappadocian Logic." Greek Orthodox Theological Review 61: 61-74.

Gerson, Lloyd P. 1994. Plotinus. (The Arguments of the Philosophers.) London; New York: Routledge.

Karfíková, Lenka. 2007. "Der Ursprung der Sprache nach Eunomius und Gregor vor dem Hintergrund der Antiken Sprachtheorien." In Gregory of Nyssa, Contra Eunomium II : an English version with supporting studies : proceedings of the 10th International Colloquium on Gregory of Nyssa (Olomouc, September 15-18, 2004). Supplements to Vigiliae Christianae,, edited by J. den 
Boeft, J. van Oort, . L. Petersen, D.T. Runia, C. Scholten and J.C.M. van Winden, 279-305. Leiden ; Boston: Brill.

Lloyd, A. C. 1990. The Anatomy of Neoplatonism. Oxford; New York: Clarendon Press.

Long, A. A. 1971. "Language and Thought in Stoicism." In Problems in stoicism, edited by A. A. Long, 75-113. London: Athlone Press.

Long, A. A., and D. N. Sedley. 1987. The Hellenistic Philosophers. Vol. 1. Cambridge; New York: Cambridge University Press. https://doi.org/10.1017/CBO9780511808050.

Long, Anthony A., and David N. Sedley. 1988. The Hellenistic Philosophers. Vol. 1, Translations of the Principal Sources with Philosophical Commentary, vol. 2, Greek and Latin Texts with Notes and Bibliography. Cambridge; New York: Cambridge University Press.

Meredith, Anthony. 1995. The Cappadocians. (Outstanding Christian Thinkers.) London: Chapman.

Meredith, Anthony. 2007. "The Language of God and Human Language (CE II 195-293)." In Gregory of Nyssa, Contra Eunomium II : an English version with supporting studies : proceedings of the 10th International Colloquium on Gregory of Nyssa (Olomouc, September 15-18, 2004). Supplements to Vigiliae Christianae,, edited by J. den Boeft, J. van Oort, . L. Petersen, D.T. Runia, C. Scholten and J.C.M. van Winden, 247-78. Leiden ; Boston: Brill. https://doi.org/10.5040/9780567697479.

Mortley, R. 1986. From word to silence 2 The way of negation, Christian and Greek, Theophaneia 31. Bonn: Hanstein.

Owen, G. E. L. 1965. The Platonism of Aristotle. London.

Price, Richard. 2009. The Acts of the Council of Constantinople of 553; with related texts on the Three Chapters Controversy. Translated Texts for Historians 51. Liverpool: Liverpool University Press. https://doi.org/10.3828/978-1-84631$\underline{178-9}$.

Radde-Gallwitz, Andrew. 2009. "Basil of Caesarea, Gregory of Nyssa, and the transformation of divine simplicity." Oxford : Oxford University Press. https://doi.org/10.1093/acprof:oso/9780199574117.001.0001.

Runia, David T. 1988. "Naming and Knowing: Themes in Philonic Theology with Special Reference to the De mutatione nominum." In Knowledge of God in the Graeco-Roman World, edited by R. Van Den Broek, Tjitze Baarda and Jaap Mansfeld, 69-91. Etudes Préliminaires Aux Religions Orientales Dans L'Empire $\quad$ Romain $112 . \quad$ Leiden: Brill. https://doi.org/10.1163/9789004296671 005.

Sandbach, F.H. 1971. "Phantasia Kataleptike." In Problems in stoicism, edited by A. A. Long, 9-21. London: Athlone Press.

Scott, Michael. 2013. Religious Language. New York: Palgrave Macmillan. 
Strange, Steven Keith. 1981. "Plotinus' Treatise On the Genera of Being: An Historical and Philosophical Study." PhD Thesis, University of Texas at Austin.

Vaggione, Richard Paul. 1976. "Aspects of Faith in the Eunomian Controversy." University of Oxford.

Van den Broek, Roelof. 1988. "Eugnostus and Aristides on the Ineffable God." In Knowledge of God in the Graeco-Roman World, edited by R. Van Den Broek, Tjitze Baarda and Jaap Mansfeld, 202-18. Etudes Préliminaires Aux Religions Orientales Dans L'Empire Romain 112. Leiden: Brill. https://doi.org/10.1163/9789004296671 012.

Wiles, Maurice. 1989. "Eunomius: hair-splitting dialectician or defender of the accessibility ofsalvation?". In The Making of orthodoxy: essays in honour of Henry Chadwick, edited by Rowan Williams, 157-72. Cambridge: Cambridge University Press. https://doi.org/10.1017/CBO9780511555350.010.

Zhyrkova, Anna. 2008. "Porphyry's Interpretation of Categories-the Neoplatonic Approach to Nominalism?". Eos 95 (2): 253-67.

Zhyrkova, Anna. 2019. “The Éminence Grise of Christology: Porphyry's Logical Teaching as a Cornerstone of Argumentation in Christological Debates of the Fifth and Sixth Centuries." Journal of Applied Logics -IfCoLog Journal of Logics and their Application 6 (6): 1109-24.

Published Online: December 24, 2020 